\title{
EDUKASI PEMAHAMAN HUKUM KESEHATAN DAN PENCEGAHAN PENULARAN COVID-19 DI KLINIK CAHAYA KEMANG KABUPATEN BOGOR
}

\author{
Isniani Ramadhani ${ }^{1}$,Putra Sang Fajar $^{2}$,Erna Harfiani ${ }^{3}$, Ratna Puspita $^{4}$ \\ ${ }^{1}$ Program Etik Mediko Legal, FK UPN Veteran Jakarta \\ Surel: Isniani@upnvj.ac.id \\ ${ }^{2}$ Program Etik Mediko Legal, FK UPN Veteran Jakarta \\ Surel: drputrasangfajar@gmail.com \\ ${ }^{3}$ Program Etik Mediko Legal, FK UPN Veteran Jakarta \\ Surel: ernaharfiani@upnvj.ac.id \\ ${ }^{4}$ Program Etik Mediko Legal, FK UPN Veteran Jakarta \\ Surel: ratnapuspita@upnvj.ac.id
}

\begin{abstract}
Indonesia is one of the countries affected by the spread of Covid-19, and to date, the morbidity rate yet can't be considered low. One area that is most affected is Kemang District, Bogor Regency. Cases in the area have been occurring due to the lack of public awareness of the symptoms, the transmission, non-compliance, and the public's ignorance of health regulations related and health protocols. The people of Kemang District need to be provided with the correct information and proper dissemination to help maintain their health and prevent transmission. It's hoped that by providing education, people at the front line can support the government's measures in fighting the pandemic.The methods used are online dissemination, online discussions, and online mentoring. This campaign is carried out by :(1) counseling on how to prevent the transmission of Covid-19; (2) providing knowledge or raising awareness of health laws related to the pandemic; (3) measuring public knowledge's of how to prevent the transmission and of health laws related to the pandemic with an online questionnaire.Short-term objectives expected: (1) increasing knowledge about various ways to prevent the Covid-19 spread in communities, (2) increasing knowledge of the people of Kemang District and the surrounding areas, about the health laws applied in the community.The dissemination takes place at the Cahaya Kemang Clinic, Bogor Regency, shows an increase in participants' knowledge through an evaluation of pre-test and post-test knowledge and a better understanding of health laws and the prevention of Covid-19.
\end{abstract}

Keywords: Covid-19, health law, health protocol, Kemang District, prevention of transmission.

\section{ABSTRAK}

Indonesia merupakan salah satu negara yang terkena dampak penyebaran Covid-19, dan sampai saat ini angka kesakitannya belum bisa dikatakan rendah. Salah satu daerah yang paling terdampak adalah Kecamatan Kemang, Kabupaten Bogor. Kasus-kasus di daerah terjadi karena kurangnya kesadaran masyarakat akan gejala, penularan, ketidakpatuhan, dan ketidaktahuan masyarakat terkait peraturan kesehatan dan protokol kesehatan.Masyarakat Kabupaten Kemang perlu diberikan informasi yang benar dan sosialisasi yang tepat untuk membantu menjaga kesehatan dan mencegah penularan. Diharapkan dengan memberikan edukasi, masyarakat di garda terdepan dapat mendukung langkah pemerintah dalam memerangi pandemi.Metode yang digunakan adalah sosialisasi online, diskusi online, dan pendampingan online. Kampanye ini dilakukan dengan :(1) penyuluhan tentang cara pencegahan penularan Covid-19; (2) memberikan pengetahuan atau meningkatkan kesadaran hukum kesehatan terkait pandemi; (3) mengukur pengetahuan masyarakat tentang pencegahan penularan dan undang-undang kesehatan terkait pandemi dengan kuesioner online. Tujuan jangka pendek yang diharapkan: (1) meningkatkan pengetahuan tentang berbagai cara pencegahan penyebaran Covid-19 di masyarakat, (2) meningkatkan pengetahuan masyarakat Kecamatan Kemang dan sekitarnya, tentang hukum kesehatan yang berlaku di masyarakat.Sosialisasi yang berlangsung di Klinik Cahaya Kemang Kabupaten Bogor ini menunjukkan adanya peningkatan pengetahuan peserta melalui evaluasi pengetahuan pre-test dan post-test serta pemahaman yang lebih baik tentang undang-undang kesehatan dan pencegahan Covid-19.

Kata Kunci : Covid-19, hukum kesehatan, Kecamatan Kemang, pencegahan penularan, protokol kesehatan.

\section{PENDAHULUAN}


Covid-19 merupakan penyakit yang disebabkan oleh virus corona atau Severe Acute Respiratory Syndrome Corona Virus -2 (SARS COV-2). Dilaporkan pertama kali di Wuhan, Tiongkok pada 31 Desember 20191 (PADK, 2020). Covid-19 dapat ditransmisikan melalui droplet (percikan air liur) orang yang terinfeksi, baik hembusan nafas, batuk, atau bersin. Molekul droplet terlalu berat dan tidak dapat bertahan di udara sehingga cepat jatuh, menempel pada permukaan benda apapun, termasuk permukaan kulit. Orang yang terinfeksi Covid-19, sebagian besar mengalami gejala ringan hingga sedang dan sisanya meninggal akibat adanya penyakit penyerta (komorbid). Penelitian terkini menjelaskan bahwa materi genetik (RNA) virus SARS-CoV-2 teridentifikasi pada sampel feses dan urin pasien Covid-19. Bukti ilmiah hasil penelitian tersebut belum terbukti sampai saat ini. (Jing Sun, Zhu Airu, Li Heying, 2020), (Wu Y, Guo C, Tang L Hong Z, Zhou J, Dong X, 2020).

Penyebaran kasus Covid di Indonesia masih sangat tinggi. Kementerian Kesehatan mencatat pasien terkonfirmasi Covid-19 pada tanggal 16 Februari 2021 sebanyak 298.452 orang dengan pasien meninggal sebanyak 10.819 orang (3,63\%) (Covid-19, 2021). Penanggulangan Covid-19 sudah diupayakan oleh pemerintah melalui peraturan yang tercantum dalam Keputusan Menteri Kesehatan RI No. HK.01.07/MENKES/328/2020 tentang Panduan Pencegahan dan Pengendalian Corona Virus Disease 2019 (Covid-19). Regulasi tersebut jelas memandu masyarakat dalam mencegah infeksi Covid-19 dan mengendalikannya agar tidak makin meluas. Dukungan masyarakat terhadap upaya pemerintah masih sangat rendah diakibatkan kurangnya pemahaman mengenai Covid-19 serta penularannya. Ketidaktaatan masyarakat terhadap aturan yang berlaku membuat masyarakat yang terpapar Covid-19 di berbagai daerah di Indonesia semakin bertambah.

Hoaks yang gigih beredar memiliki kemampuan membujuk masyarakat umum untuk tidak mempercayai bahwa virus Covid-19 dapat menjadi suatu ancaman (Shihab, n.d.). Seperti misalnya berita tidak benar mengenai cuaca dan iklim Indonesia yang tidak akan menimbulkan penyebar luasan Covid-19, atau tidak benar berita mengenai ramuan serta obat-obat yang dapat mencegah kita dari terinfeksi Covid-19 atau meminum minyak kayu putih (Palilingan, 2020).

Ada pula hoax yang menyatakan bahwa korban Covid-19 yang telah meninggal tidak akan menyebarkan virus dan virus akan mati jika inangnya juga mati (Shihab, n.d.). Perebutan jenazah Covid-19 oleh pihak keluarga sering terjadi di beberapa wilayah di Indonesia. Protokol pemakaman jenazah Covid-19 yang ditetapkan pemerintah dianggap sebagai sesuatu yang menakutkan oleh hampir seluruh masyarakat, karena jenazah tidak dapat diperlakukan sebagaimana mestinya oleh keluarga. Demikian juga kebijakan pemerintah mengenai pembatasan sosial berskala besar dianggap menjadi beban berat bagi masyarakat kecil karena ada dampak lain yaitu dampak sosial, ekonomi maupun mental.

Namun sejatinya, pemerintah bertujuan baik dalam mengeluarkan kebijakan-kebijakan atau regulasi berkaitan dengan Covid-19 ini. Negara mempunyai kewajiban melindungi hak seluruh warga negaranya. Hal ini tertuang dalam Pembukaan UUD 1945 yang merupakan cita-cita Bangsa Indonesia. Kemudian WHO, dalam konstitusinya tahun 1948 menegaskan bahwa, "memperoleh derajat Kesehatan yang setinggi-tingginya merupakan hak asasi bagi setiap orang". Amandemen UUD 1945 tahun 2002 juga menegaskan bahwa kesehatan bagian dari Hak Asasi Manusia.

"Setiap orang berhak hidup sejahtera lahir dan batin, bertempat tinggal dan mendapat lingkungan hidup yang baik dan sehat serta berhak memperoleh pelayanan Kesehatan," bunyi pasal 28H ayat (1) UUD 1945. (Republik Indonesia, 2002). Pasal tersebut yang terdapat dalam Amandemen UUD 1945, menimbulkan perubahan cara pandang sangat luar biasa. Kesehatan tidak lagi dipandang sebagai urusan pribadi saja, tetapi suatu hak hukum (legal right) yang di jamin negara. Akibatnya, untuk memerangi kedaruratan penyakit terkait zoonosis, pemerintah mengadopsi Hukum Kesehatan Internasional dengan menerbitkan Undang-Undang Nomor 6 
Tahun 2018 tentang Kekarantinaan Kesehatan. Pemerintah juga mengeluarkan banyak peraturan lain yang mengatur upaya perlindungan dan pencegahan penyakit menular.

Pemerintah mengeluarkan beberapa regulasi dalam upaya penanggulangan wabah Covid-19, mengacu pada Undang-Undang Hukum Kesehatan Internasional dan Undang-Undang Kekarantinaan Kesehatan, yaitu :

1. Instruksi Presiden Nomor 4 Tahun 2020 tentang refocussing kegiatan, realokasi anggaran serta pengadaan barang dan jasa dalam rangka percepatan penanganan Corona Virus Disease 2019 (COVID-19) .

2. Keputusan Presiden Nomor 11 tahun 2020 tentang Penetapan Kedaruratan Kesehatan Masyarakat COVID-19

3. Keputusan Presiden Nomor 12 Tahun 2020 tentang penetapan bencana non alam penyebaran Corona Virus Disease 2019 (COVID-19) sebagai Bencana Nasional.

4. Peraturan Pemerintah No. 21 tahun 2020 tentang Pembatasan Sosial Berskala Besar dalam rangka Percepatan Penanganan Corona Virus Disease (COVID-19) ditetapkan di Jakarta pada tanggal 31 Maret 2020 oleh Presiden Joko Widodo.

5. Keputusan Presiden Nomor 7 Tahun 2020 Tentang Gugus Tugas Percepatan Penanganan Corona Virus Disease 2019

6. Keputusan Presiden Nomor 9 Tahun 2020 tentang Perubahan Atas Keputusan Presiden Nomor 7 Tahun 2020 Tentang Gugus Tugas Percepatan Penanganan Corona Virus Disease 2019 (COVID-19).

Posbindu (Pos Pembinaan Terpadu) merupakan satu dari pusat kegiatan kesehatan yang dibentuk oleh komunitas dan pemerintah dalam rangka deteksi dini dan monitor faktor risiko penyakit yang tidak disebabkan oleh mikroba. Penyakit-penyakit tersebut seperti : hipertensi, penyakit jantung, diabetes mellitus), dan dilakukan kepada lansia ataupun pra lansia, serta diimplementasikan dengan aktivitas terintegrasi, rutin dan periodik (Kemenkes RI, 2016). Sedangkan pada Pusat Pelayanan Kesehatan Tingkat 1 yang bekerjasama dengan BPJS, kegiatan tersebut diintegrasikan dalam program pengelolaan penyakit kronis (prolanis).

Desa Pondok Udik merupakan salah satu daerah yang berbatasan dengan Jakarta maupun Depok yang saat ini merupakan Zona Merah penyebaran Covid-19. Hal ini cukup menyebabkan masyarakat dihantui ketakutan dan kecemasan / stress akan terjangkit penyakit ini. Perlu informasi yang tepat yang dapat disampaikan ke masyarakat. Kader kesehatan sebagai salah satu ujung tombak kesehatan masyarakat sangat potensial untuk dibekali pengetahuan tentang pencegahan penularan Covid-19 dan pengetahuan hukum kesehatan berkaitan dengan pandemi Covid-19.

Mitra Tim Abdimas Fakultas Kedokteran Universitas Pembangunan Nasional Veteran Jakarta adalah Klinik Cahaya Kemang. Klinik ini terletak di Desa Pondok Udik yang merupakan bagian dari Kecamatan Kemang, Kabupaten Bogor. Mempunyai luas wilayah 3,23 $\mathrm{km}^{2}$ terdiri dari 11.90 Ha daerah perumahan; 13,10 Ha merupakan ladang/tegal, $40 \mathrm{Ha}$ situ/waduk dan $50 \mathrm{Ha}$ pekarangan serta $40 \mathrm{Ha}$ tanah rawa (Kemang, n.d.). Kepadatan populasi di Desa Pondok Udik adalah $2611 \mathrm{jiwa} / \mathrm{km}^{2}$. Di tahun 2016, sebanyak 1417 orang bekerja sebagai karyawan, yang merupakan profesi terbanyak di Desa Pondok Udik (Kemang, n.d.). Klinik Cahaya Kemang memiliki 125 peserta prolanis yang secara periodik di ukur tekanan darah dan kadar gula darah puasa. Dari 125 pasien, 85 orang menderita hipertensi ( $68 \%$ ) dan 40 orang mendertia DM ( 32 $\%)$. Peserta prolanis yang aktif diharapkan dapat menjadi kader kesehatan yang membantu menyebarkan pengetahuan yang tepat tentang pencegahan penularan Covid-19 dan pengetahuan mengenai hukum kesehatan yang berkaitan dengan pandemi Covid-19. 


\section{METODE PELAKSANAAN PKM}

Sebelum melakukan giat abdimas tentang Edukasi Pencegahan Penularan Covid-19 Dan Pemahaman Hukum Kesehatan Terkait Pandemi Covid-19 di Klinik Cahaya Kemang Bogor, dilakukan persiapan antara lain :

1) Koordinasi dengan Kepala Klinik Cahaya Kemang, Bogor, Jawa Barat beserta jajarannya sebagai mitra abdimas. Koordinasi sangat penting untuk kelancaran kegiatan. Koordinasi sebanyak dua kali sudah cukup mematangkan pelaksanaan kegiatan;

2) Materi yang akan disajikan dalam penyuluhan ditulis dalam bentuk power point;

3) Membuat materi pendukung lain berupa poster dan booklet berisi informasi pengetahuan untuk masyarakat mengenai cara mencegah penularan Covid-19 beserta informasi berkaitan dengan hukum kesehatan terkait pandemi Covid-19, sehingga lebih memotivasi masyarakat untuk ikut aktif menyebarkan pengetahuan tersebut;

4) Membuat video edukasi tentang Pencegahan Penularan Covid-19 dan Pemahaman Hukum Kesehatan Terkait Pandemi Covid-19. Tujuan pembuatan video agar dapat diserap secara berulang-ulang setelah penyuluhan dan dapat di lihat masyarakat banyak.

5) Menyusun kuesioner berupa pre test dan post test yang terdiri dari sepuluh pertanyaan untuk pre test dan sepuluh pertanyaan untuk post test. Kuesioner ini bertujuan untuk mengetahui seberapa besar pemahaman dan pengetahuan peserta sebelum dan sesudah penyuluhan serta untuk mengetahui efektifitas kegiatan penyuluhan.

Kegiatan Pengabdian Kepada Masyarakat dilakukan dengan dua tahapan, yaitu penyuluhan serta tanya jawab tentang pencegahan penularan Covid-19 dan Pemahaman Hukum Kesehatan Terkait Pandemi Covid-19.

\section{Tahap Penyuluhan}

Penyuluhan kepada masyarakat merupakan transfer ilmu terbaik dan termudah untuk mengedukasi masyarakat tentang pentingnya Pencegahan Penularan Covid-19 dan Hukum Kesehatan Terkait Pandemi Covid-19, sehingga masyarakat dapat termotivasi untuk berbagi pengetahuan kepada masyarakat sekitarnya dan akan membantu program pemerintah dalam menanggulangi Covid-19. Materi penyuluhan mengenai pengenalan virus Covid-19, gejala, cara mendeteksi Covid-19, pencegahan dari terinfeksi Covid-19 seperti menjaga protokol kesehatan $6 \mathrm{M}$, cara meningkatkan daya tahan tubuh dengan pola hidup sehat dan vaksinasi. Adapun materi Hukum Kesehatan yang diberikan mengenai Pengertian Hukum itu sendiri, Mengapa kesehatan di atur oleh negara, Hukum Kesehatan Internasional (International Health Regulation) serta Prinsip dan Tujuannya, Undang-Undang Kekarantinaan, Bagaimana respon pemerintah saat WHO mengumumkan tentang pandemi Covid-19, bagaimana negara mencegah sumber penular dari negara-negara lain dan peran bandara, pelabuhan dan perbatasan, bagaimana regulasi mengenai pemulasaran jenasah dan sanksi bagi penjemput paksa jenasah covid-19 serta bagi yang tidak patuh terhadap aturan pemerintah terkait covid-19. Peserta yang hadir terdiri dari bapak-ibu peserta prolanis Klinik Cahaya Kemang yang tersebar di beberapa wilayah Kemang dan sekitar Kemang, Kabupaten Bogor. Teknis pelaksanaannya, sebelum di mulai penyuluhan, peserta diberikan pre test yang berisi beberapa pertanyaan pengetahuan tentang Pencegahan Penularan Covid-19 dan Pemahaman Hukum Kesehatan Terkait Pandemi Covid-19 secara umum. Tujuannya untuk mengetahui sejauh mana tingkat pengetahuan peserta terhadap materi yang akan disampaikan. Dilanjutkan dengan penyuluhan tentang Pencegahan Penularan Covid19 dan Pemahaman Hukum Kesehatan Terkait Pandemi Covid-19. Acara ditutup dengan pengisian post test. Target pelaksanaan post test untuk mengetahui sejauh mana materi yang disampaikan terserap oleh peserta, diharapkan terjadi peningkatan pengetahuan peserta sehingga transfer pengetahuan tercapai. Disamping itu, hadiah buku saku tentang Pencegahan Penularan Covid-19 dan Pemahaman Hukum Kesehatan Terkait Pandemi Covid-19 diberikan bagi peserta 
yang aktif. Booklet tersebut mengandung informasi penting dan bermanfaat berkenaan dengan Pandemi Covid-19 sebagai bekal untuk diri dan sumber informasi yang dapat disebarkan ke masyarakat.

\section{Tahap Tanya Jawab}

Setelah penyuluhan, diberikan kesempatan bagi peserta untuk bertanya sehingga ada komunikasi dua arah antara pengabdi dan para peserta. Serta memberi keleluasaan peserta untuk menggali keingintahuan sebanyak-banyaknya tentang cara pencegahan penularan Covid-19 dan informasi hukum kesehatan terkait pandemik Covid-19.

\section{HASIL DAN PEMBAHASAN}

Pemberian transfer pengetahuan kepada peserta prolanis Klinik Cahaya Kemang dilakukan secara daring pada tanggal 12 Juli 2021. Dilakukan oleh tim Abdimas FK UPN Veteran Jakarta beserta dua mahasiswa Fakultas Kedokteran UPNVJ semester empat yang ikut berperan aktif dalam kegiatan penyuluhan tersebut. Poster serta materi paparan yang dibuat semenarik mungkin serta penggunaan bahasa yang sederhana dibuat tim Abdimas untuk mendorong minat peserta menyimak dan membaca apa yang disampaikan tim.

Evaluasi hasil pre test didapatkan bahwa belum semua peserta memahami pentingnya mengetahui pencegahan penulan Covid-19. Demikian pula tentang pengetahuan hukum kesehatan terkait pandemi Covid-19. Banyak dari mereka yang belum memahami tentang Pencegahan Penularan Covid-19 dan Pemahaman Hukum Kesehatan Terkait Pandemi Covid-19.

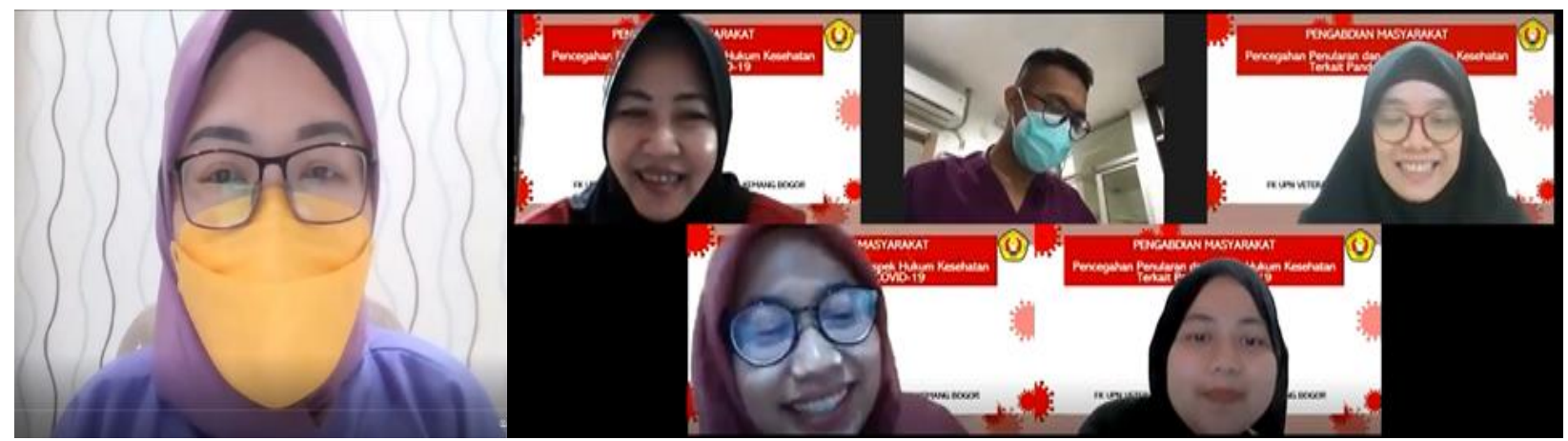

Gambar 1. Sambutan dari Ka Klinik Cahaya Kemang dan Penyuluhan Pencegahan Penularan Covid-19 dan Pemahaman Hukum Kesehatan Terkait Pandemi Covid-19 oleh Tim Penyuluh Universitas Pembangunan Nasional Veteran Jakarta Sumber: Data Primer

Hasil pre test yang di dapat dari seluruh peserta, diperoleh nilai rata-rata pemahanan mereka terhadap materi yang akan diberikan sebesar 68,57 dengan standar deviasi antara 51, 167 85,973 dan hasil meningkat pada saat post test yaitu 80,95 dengan standar deviasi antara 59,191 102,141 . Hal ini menandakan bahwa transfer pengetahuan dari para pengabdi kepada masyarakat (peserta) berhasil dilakukan dengan bukti adanya kenaikan nilai rata-rata post test peserta. 

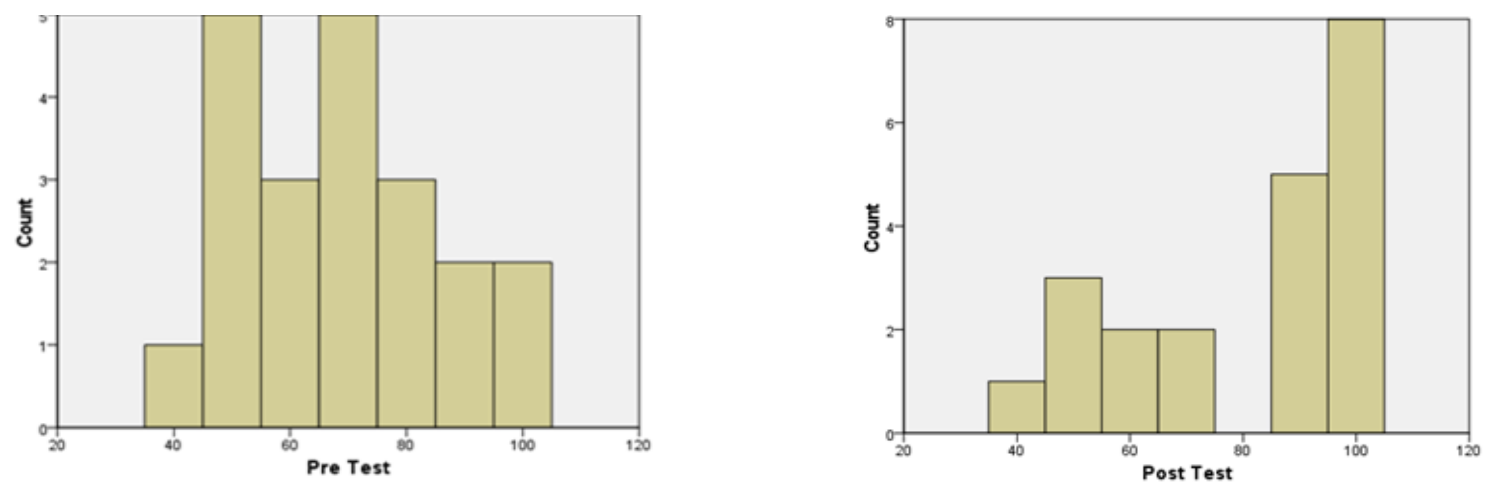

\section{Descriptive Statistics}

\begin{tabular}{l|r|r|r|r|r} 
& N & Minimum & Maximum & Mean & Std. Deviation \\
\hline Pre Test & 21 & 40 & 100 & 68.57 & 17.403 \\
\hline Post Test & 21 & 40 & 100 & 80.95 & 21.191 \\
\hline Valid N (listwise) & 21 & & & & \\
\hline
\end{tabular}

Gambar 2. Hasil Uji Statistik pre dan post test Pengetahuan Pencegahan Penularan Covid-19 dan Pemahaman Hukum Kesehatan Terkait Pandemi Covid-19.

Data kemudian di analisa secara statistik dengan menggunakan Uji Alternative Wilcoxon dan berdasarkan output "test statistics" diketahui Asymp. Sig (2-tailed) bernilai 0,001. Karena nilai 0,001 lebih kecil dari 0,05 maka dapat disimpulkan bahwa hipotesa diterima. Artinya ada perbedaan pengetahuan mengenai pencegahan penularan Covid-19 dan pemahaman hukum kesehatan terkait pandemi Covid-19 untuk pre dan post test. Sehingga dapat disimpulkan pula bahwa, ada pengaruh penyuluhan pencegahan penularan Covid-19 dan pemahaman hukum kesehatan terkait pandemi Covid-19 pada peserta prolanis Klinik Cahaya Kemang.

\begin{tabular}{|c|c|c|c|c|}
\hline \multicolumn{5}{|c|}{ Ranks } \\
\hline & & $\mathrm{N}$ & Mean Rank & $\begin{array}{c}\text { Sum of } \\
\text { Ranks }\end{array}$ \\
\hline \multirow[t]{4}{*}{ Post Test-Pre Test } & Negative Ranks & $0^{a}$ & .00 & .00 \\
\hline & Positive Ranks & $15^{b}$ & 8.00 & 120.00 \\
\hline & Ties & $6^{c}$ & & \\
\hline & Total & 21 & & \\
\hline
\end{tabular}

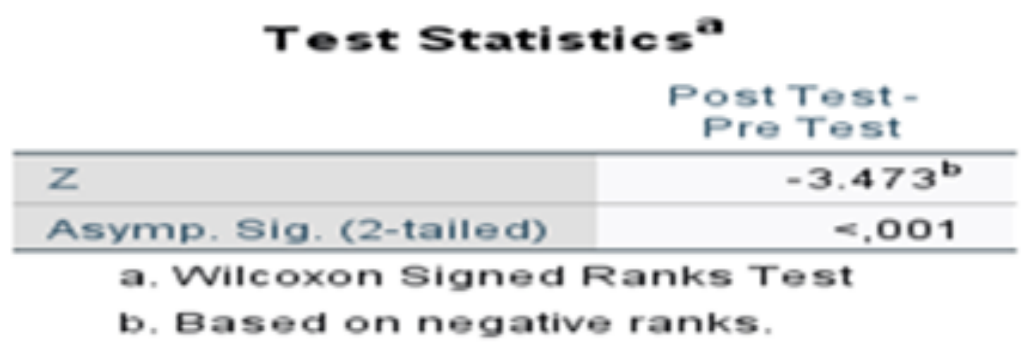

Gambar 3. Hasil Uji test Statistics Penyuluhan Pencegahan Penularan Covid-19 dan Pemahaman Hukum Kesehatan Terkait Pandemi Covid-19. 


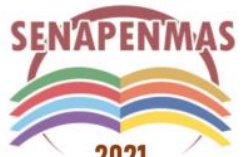

2021
Seminar Nasional Hasil Penelitian dan Pengabdian Kepada Masyarakat 2021 Pengembangan Ekonomi Bangsa Melalui Inovasi Digital Hasil Penelitian dan Pengabdian Kepada Masyarakat Jakarta, 21 Oktober 2021

Dari evaluasi jawaban peserta penyuluhan, nampak bahwa peserta masih sulit membedakan definisi jamu, obat herbal terstandar dan obat fitofarmaka. Ketiga obat tersebut sebenarnya sangat sering mereka temui dan konsumsi namun tetap saja mereka belum dapat membedakan definisi ketiganya. Jamu merupakan obat bahan alam yang penyajiannya masih dalam bentuk aslinya. Keamanan dan kegunaannya masih berdasarkan pengalaman turun temurun. Jika bahan asli ini diikutkan pada uji pra klinis kepada hewan coba dan ternyata bermanfaat (lolos), maka jamu tersebut disebut obat herbal terstandar. Apabila kemudia lolos uji klinis, maka jamu tersebut disebut Fitofarmaka karena keamanan, khasiat, bahan baku semua sudah terstandar. Implikasi mengetahui perbedaan ketiganya, masyarakat akan memahami jumlah dosis atau takaran yang dibutuhkan untuk penyakit tertentu dan tidak asal meminum jamu tanpa mengetahui dosis yang digunakan dan manfaatnya. Demikian juga dengan pertanyaan tentang landasan negara mengatur kesehatan. Ada 10 peserta yang masih salah dalam memberikan jawaban. Jika peserta memahami alasan negara mengatur kesehatan, implikasinya masingmasing individu mampu bertanggungjawab terhadap kesehatan diri sendiri dan kesehatan orang lain baik selama maupun di luar pandemi Covid-19 serta berkesadaran secara pribadi untuk patuh pada aturan yang dibuat pemerintah.

\section{Frequently missed questions}

$\begin{array}{lc}\text { Question } & \text { Correct responses } \\ \begin{array}{l}\text { 4. Bahan /ramuan berupa tumbuhan, hewan, bahan mineral atau campuran bahan yg dipercaya } \\ \text { secara pengalaman secara turun menurun (empiris) digunakan untuk pengobatan disebut }\end{array} & 10 / 21 \\ \begin{array}{l}\text { 6. Apa landasan hukum Negara mengatur kesehatan masyarakat, kecuali: } \\ \text { 7. Pasal-pasal yang menetapkan sanksi bagi penjemput paksa jenazah Covid-19, kecuali }\end{array} & 9 / 21 \\ \begin{array}{l}\text { 9. Aturan yang dibuat oleh Negara dalam mengatur pergaulan hidup masyarakat. Merupakan } \\ \text { pengertian dari? }\end{array} & 7 / 21 \\ \begin{array}{l}\text { 10. MUI telah mengeluarkan fatwa prosedur memandikan jenazah yang terpapar Covid-19. } \\ \text { Tertuang pada fatwa MUI nomor \& tahun berapa? }\end{array} & 8 / 21\end{array}$

Gambar 4. Jawaban pertanyaan yang paling banyak salah Sumber: Data Primer 2021

Para peserta bersemangat bertanya tentang pencegahan penularan Covid-19 dan pemahaman hukum kesehatan terkait pandemi Covid-19 dalam sesi tanya jawab. Selain itu, mereka kurang paham dan kurang terpapar, khususnya berkaitan dengan pandemi Covid-19. Pemberian materi dengan bahasa yang sederhana sangat dipahami peserta. Ini membantu mereka mengerti mengapa harus dilakukan protokol kesehatan, mengapa diseluruh dunia melakukan hal yang sama dan mengapa ada suatu negara yang sudah bisa lepas dari menggunakan masker.

Pendekatan kepada masyarakat mengenai hukum terutama di daerah-daerah dirasa sangat perlu untuk membantu negara mengatasi pandemi yang entah sampai kapan selesai. Dengan bahasa yang mudah dimengerti dan sederhana, masyarakat akan paham dengan langkah-langkah yang dilakukan pemerintah. Ada hak orang lain yang dilanggar jika kita tetap memaksa untuk tidak percaya akan adanya Covid-19 dan tidak mengindahkan larangan pemerintah.

Pemerintah pun dalam memberi hukuman sangat adil dan bertahap sama seperti bapak-ibu dalam sistem organisasi terkecil masyarakat yaitu keluarga, memberi hukuman yang mendidik 
kepada anak-anaknya. Dimulai dari yang ringan hingga berat jika anak-anak tidak mengindahkan aturan dalam keluarga. Demikian pula dengan negara yang memberikan sanksi bagi mereka yang tidak mengindahkan aturan yang dibuat negara agar pandemi dapat teratasi dengan baik. "Barang siapa pada waktu rakyat datang berkerumun dengan sengaja tidak segera pergi setelah diperintah tiga kali oleh atau atas nama penguasa yang berwenang, diancam karena ikut serta perkelompokan dengan pidana penjara paling lama empat bulan dua minggu atau pidana denda paling banyak sembilan ribu rupiah". Demikian bunyi pasal 218 KUH Pidana. Dapat di lihat penerapan pasal tersebut, pada awal pandemi, pemerintah masih memberikan hukuman ringan seperti menyapu jalan, menjadi duta pakai masker dan sebagainya. Pada peringatan kedua, naik sedikit menjadi bayar denda dengan sejumlah uang. Peringatan ketiga, seperti bunyi pasal 218 KUH Pidana, karena sudah diberi peringatan maka hukuman lebih berat, yaitu kurung badan. Pasal lain yang digunakan dalam masa pandemi ini adalah pasal 212 KUH Pidana dan UndangUndang Nomor 6 Tahun 2018 tentang Kekarantinaan Kesehatan, pasal 93.

Kebutuhan masyarakat akan pengetahuan hukum serta upaya-upaya pencegahan penularan Covid-19 sangat terlihat dari feedback yang diberikan para peserta di akhir acara. Materi yang diberikan menarik serta bersedia mengikuti kegiatan yang akan datang.

\begin{tabular}{llccc}
\hline No & \multicolumn{1}{c}{ Pertanyaan } & Tidak & Netral & Iya \\
\hline & Apakah materi yang disampaikan menarik? & $0 \%$ & $0 \%$ & $100 \%$ \\
\hline 2 & Apakah materi yang disampaikan jelas? & $0 \%$ & $14,3 \%$ & $85,7 \%$ \\
\hline 3 & Apakah kegiatan berjalan dengan lancar? & $0 \%$ & $9,5 \%$ & $90,5 \%$ \\
\hline 4 & $\begin{array}{l}\text { Apakah bapak/Ibu bersedia mengikuti kegiatan } \\
\text { yang akan datang? }\end{array}$ & $0 \%$ & $9,5 \%$ & $90,5 \%$ \\
\hline
\end{tabular}

Gambar 5. Feedback peserta terhadap acara penyuluhan pengabdian kepada masyarakat Fakultas Kedokteran Universitas Pembangunan Nasional Veteran Jakarta

Sumber: Data Primer 2021

\section{KESIMPULAN DAN SARAN}

Angka kesakitan dan angka kematian karena Covid-19 di seluruh dunia dan Indonesia masih sangat tinggi. Perlu perhatian yang komprehensif untuk menanggulangi penyebaran serta kematian akibat Covid-19. Memberikan penyuluhan atau edukasi ke kelompok-kelompok masyarakat di daerah - daerah adalah salah satu pendekatan yang dapat dilakukan. Terutama kepada kader kesehatan yang merupakan ujung tombak kesehatan masyarakat yang sangat potensial untuk dibekali pengetahuan tentang pencegahan penularan Covid-19 dan pemahaman hukum kesehatan terkait Covid-19.

Berdasarkan hasil pre-test dan post-test serta pembahasan dapat ditarik kesimpulan bahwa transfer pengetahuan dengan cara penyuluhan kepada peserta prolanis Klinik Cahaya Kemang dapat meningkatkan pemahaman mengenai pencegahan penularan Covid-19 dan pemahaman hukum kesehatan terkait Covid-19 dengan mengikuti tahapan-tahapan seperti pembuatan poster; pengisian pre-test; penyuluhan dengan alat bantu video dan power point yang menarik, post-test; tanya jawab dengan pemberian booklet bagi pertanyaan terbaik dan bagi peserta dengan jawaban yang benar.

Poster yang menarik dapat menarik minat peserta membaca pengetahuan yang ingin dibagikan sebelum acara dimulai. Tujuan mengetahui tingkat pemahaman awal peserta dapat diketahui pada tahapan pre test. Pada tahap transfer pengetahuan dilakukan melalui video dan power point serta bahasa yang sederhana dan mudah dipahami peserta. Keberhasilan penyampaian transfer pengetahuan dapat dilihat dari hasil evaluasi post-test dan tanya jawab dengan peserta. 


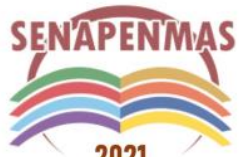

2021
Seminar Nasional Hasil Penelitian dan Pengabdian Kepada Masyarakat 2021 Pengembangan Ekonomi Bangsa Melalui Inovasi Digital Hasil Penelitian dan Pengabdian Kepada Masyarakat Jakarta, 21 Oktober 2021

\section{Ucapan Terima Kasih}

Tim Abdimas mengucapkan terima kasih kepada Klinik Cahaya Kemang Kabupaten Bogor, LPPM UPN Veteran Jakarta, FK UPN Veteran Jakarta, Amelia Salsabila, Indah Rahma Dewi.

\section{REFERENSI}

Covid-19, S. P. (2021). Peta sebaran covid-19. Diakses dari https://covid19.go.id/peta-sebaran-covid19

Sun, J., Airu, Z., et al (2020). Isolation of infectious SARS-CoV-2 from urine of a covid-19 patient. Emerging Microbes \& Infections, 9(1), 991-993. Retrieved from https://www.tandfonline.com/doi/full/10.1080/22221751.2020.1760144

Kemang, K. (2016). Kecamatan Kemang-Bogor. Diakses dari https://kecamatankemang.bogorkab.go.id/

Kemenkes RI. (2016). Pedoman umum pos pembinaan terpadu penyakit tidak menular (pp. 916). Diakses dari http://p2ptm.kemkes.go.id/uploads/2016/10/Pedoman-Umum-PosPembinaan-Terpadu-Penyakit-Tidak-Menular.pdf

PADK, K. (2020). Hindari lansia dari Covid-19. Pusat Analisis Determinan Kesehatan Kemenkes RI. Diakses dari http://www.padk.kemkes.go.id/article/read/2020/04/23/21/hindari-lansia-dari-covid19.html

Palilingan, T. (2020, April 20). Aspek hukum dalam penanganan wabah Covid-19. Diakses dari http://manadopost.id/read/2020/04/20/ASPEK-HUKUM-DALAM-DALAMPENANGANAN-WABAH-COVID-19/67536

Shihab, N. (2020). Melawan-stigma-Corona @ www.narasi.tv. Diakses dari https://www.narasi.tv/catatan-najwa/melawan-stigma-corona

$\mathrm{Wu}, \mathrm{Y}$., et al. (2020). Prolonged presence of SARS-CoV-2 viral RNA in faecal samples. PubMed.Gov, 434-435. Retrieved from https://doi.org/10.1016/S2468-1253(20)30083-2 
Seminar Nasional Hasil Penelitian dan Pengabdian Kepada Masyarakat 2021

Pengembangan Ekonomi Bangsa Melalui Inovasi Digital Hasil Penelitian dan

Pengabdian Kepada Masyarakat

Jakarta, 21 Oktober 2021

(halaman kosong) 